\title{
Selvmord og personlighetsforstyrrelser
}

Ved Lars Mehlum

\section{En del mennesker sliter med kroniske selumordstanker og gjør stadig forsøk på å skade seg eller ta sitt eget liv. Dette kan vaere uttrykk for problemer som er knyttet til personlighetsfungeringen,} som vi skal se i denne artikkelen.

Flere typer psykiske lidelser medfører $\varnothing \mathrm{kt}$ selvmordsfare, slik som alvorlig depresjon, schizofreni eller rusmisbruk. Dette er tilstander som gir alvorlige symptomer, men symptomenes styrke kan svinge sterkt over tid, og det er gjerne i perioder med sterke symptomer at selvmordsfaren er st $\varnothing$ rst. Da er det viktig at vi gir rask og effektiv hjelp slik at situasjonen kommer under kontroll, og dette er en viktig oppgave for det psykiske helsevern. Mange mennesker sliter imidlertid med psykiske problemer som primært ikke gir seg utslag i symptomer som nevnt ovenfor, men der problemene snarere er knyttet til hvordan personligheten fungerer. Da snakker vi om personlighetsforstyrrelser. Det finnes flere typer av personlighetsforstyrrelser, og i denne artikkelen skal vi se nærmere på de variantene som er knyttet til $\varnothing \mathrm{kt}$ selvmordsfare og hvordan vi kan møte noen av de utfordringene som dette gir oss i det forebyggende arbeidet.

En rekke personlighetstrekk er isolert sett kjent for å ha en sammenheng med selvmordsrisiko. Det gjelder for eksempel uttalt impulsivitet, aggressivitet eller lav selvfølelse. Personer som har en tendens til å oppleve at det som skjer med dem $i$ livet ligger helt utenfor deres egen kontroll ("det spiller ingen rolle hva jeg gjør"), som ikke klarer å avgrense negative hendelser i tid og rom ("jeg făr det aldri til") eller som har mangelfullt utviklede problemløsningsevner, kan likeledes lettere enn andre komme inn i en suicidal prosess dersom det oppstår vansker i livet. Alle disse egenskapene forteller oss noe om personens kognitive stil og mer eller mindre godt utviklede mestringspotensiale. Ved personlighetsforstyrrelser er problemene uttalt, og det dreier seg om et sett med trekk ved personligheten som medfører sviktende evne til å mestre de vanlige utfordringene i livet og bevare en rimelig likevekt. Problemene som oppstår, er ikke avgrenset i tid eller til snevre områder i livet, men er gjennomgripende og vedvarende. I dag er det vanlig å skille

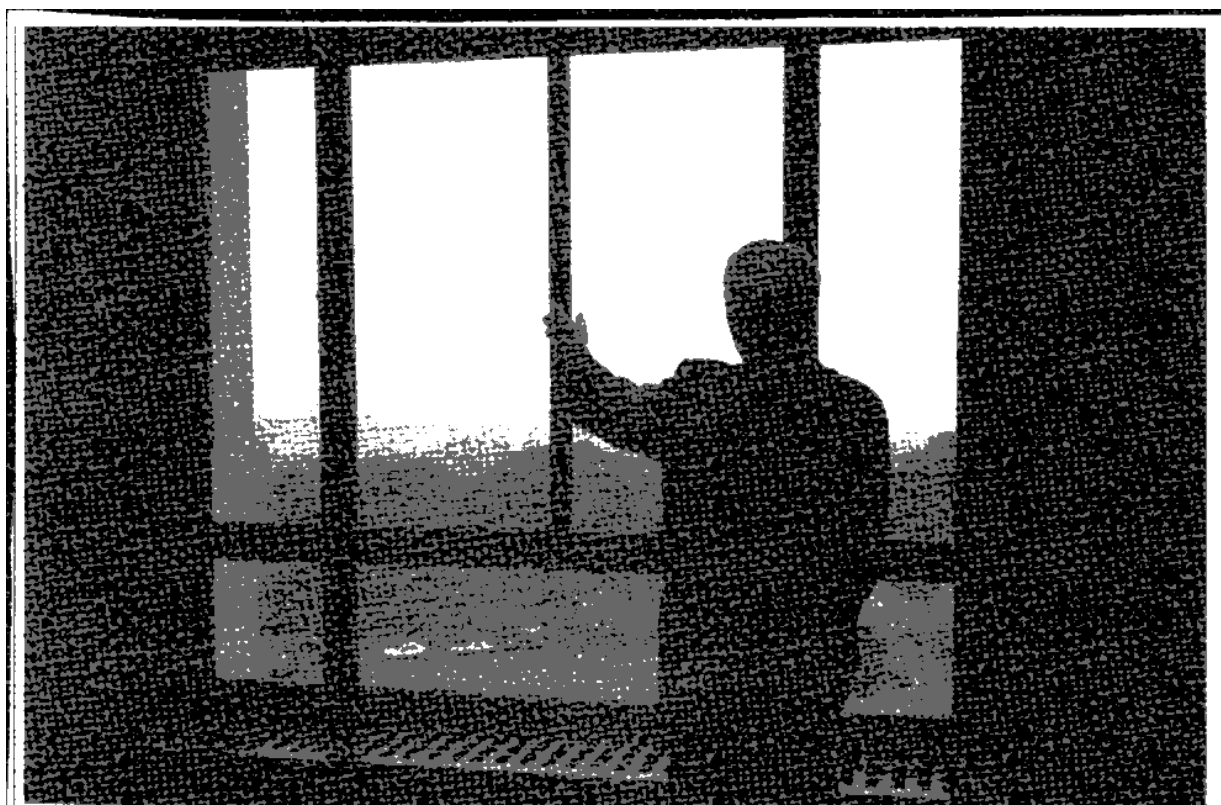

mellom en rekke ulike varianter av personlighetsforstyrrelse, men det er stor overlapping mellom de ulike typene.

Kliniske observasjoner og forløpsstudier har vist at det særlig er tre typer personlighetsforstyrrelser som medf $\varnothing$ rer $\varnothing \mathrm{kt}$ selvmordsrisiko; borderline eller ustabil personlighetsforstyrrelse, antisosial personlighetsforstyrrelse og hysteriform personlighetsforstyrrelse. Alle tilhører de gruppen av de såkalte emosjonelle eller dramatiserende personlighetsforstyrrelser. Siden det i første rekke er gruppen av borderline personlighetsforstyrrete som vi som hjelpere ofte får å gjøre med i kliniske og andre sammenhenger, skal vi i denne artikkelen konsentrere omtalen om disse.

\section{Litt om epidemiologi}

Hvor stor andel av dem som ender opp i selvmord, har en personlighetsforstyrrelse? Flere forskningsprosjekter har s $\varnothing \mathrm{kt}$ å belyse dette spørsmålet. Svaret man får, vil jo i stor utstrekning avhenge av utvalget som unders $\varnothing$ kes. Den beste studien hittil er den finske nasjonale psykologiske autopsistudien der man inngående undersøkte alle selvmord i Finland i løpet av et helt år. Man fant at i 4 prosent av alle mannlige suicidtilfeller og 12 prosent av kvinnelige suicidtilfeller var det mulig å påvise borderline personlighetsforstyrrelse (Henriksson, 1993). I en mindre anlagt svensk-amerikansk studie så man nærmere på tilfeller av selvmord blant unge. Her fant man at ved mellom 30 og 40 prosent av selvmord blant unge under 30 år var det mulig å påvise borderline personlighetsforstyrrelse (Rich og Runeson, 1992).

Oppfølgingsstudier av pasienter som har fått diagnosen borderline personlighetsforstyrrelse har lært oss at dette er en gruppe som i utgangspunktet har høy selvmordsrate, men der mye trolig kan vinnes ved å sette inn forebyggende tiltak. En gjennomgang av forskningslitteraturen tyder på at mellom 3 og 10 prosent av pasientene ender opp i selvmord i løpet av en 10-20 års periode (Mehlum et al, 1994). Kombinasjonen av borderline personlighetsforstyrrelse og alvorlig depresjon $\varnothing$ ker selvmordsrisikoen ytterligere.

Dersom pasienten i tillegg sliter med rusmisbruk, viser oppfølgingsstudiene at selvmordsrisikoen $\varnothing$ ker ytterligere (Stone, 1987). Pasienter som selv avbryter behandlingen eller skriver seg ut mot sykehusets råd ser også ut til å løpe større risk enn andre for senere å d $\varnothing$ ved selvmord 
(Kjelsberg et al, 1991). Risikoen for selvmord blant pasienter med borderline personlighetsforstyrrelse ser videre ut til å være st $\varnothing$ rst de første 4-5 år etter utskrivning, og det er i aldersgruppen 20-30 år at risikoen er størst. Det er også i disse årene at de fleste opplever de sterkeste symptomene. Det har vært hevdet at lidelsen i noen grad "brenner ut" når pasienten blir eldre. Mange har derfor pekt på at det burde være et viktig mål å berge pasienten over denne vanskelige fasen i livet.

\section{Ikke bare selvmord}

Borderline personlighetsforstyrrelse har vært kalt "den suicidale personlighetsforstyrrelse". Det er ikke bare den nevnte faren for fullført selvmord som gjør at en slik betegnelse kan ha noe for seg. Personer med borderlinesyndromet utviser ofte et helt spekter av selvdestruktive atferdsformer. Det kan dreie seg om impulsiv risikoatferd (for eksempel farlig sex eller risikofylt bruk av våpen eller farlig utstyr), rusmisbruk eller utagering av sterke emosjoner. Borderlinepersoner har ofte selvmordstanker, og disse tankene ser ut til å være kronisk til stede i større grad enn hos personer uten borderline personlighetstrekk (Mehlum et al, 1994).

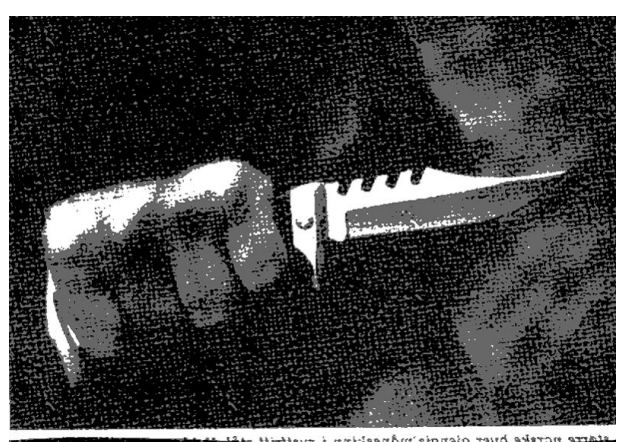

Mange borderlinepasienter tyr til selvmutilering (det å tilføre seg selv smerte eller skade uten å ha noen suicidal hensikt med handlingen) som middel til å oppnå en viss symptomlette fra intenst smertefulle følelser. Vi ser tydelig sporene etter dette på pasientens underarmer i form av utallige sigarettbrennemerker eller risp fra skarpe gjenstander. Pasienten kan også tilføre seg fysisk smerte for å stoppe dissosiasjon - en følelsesmessig tilstand som kan skape kaos, angst eller panikk. Dissosiasjon er ofte en avverge mot invaderende og retraumatiserende minner eller smertefulle følelser. Hos borderlinepasienter forekommer ofte dissosiasjon, og dette kan ses som en konsekvens av tidligere psykiske traumer. Ja, tilstedeværelsen av dissosiative symptomer ses av mange klinikere som en mark $\varnothing \mathrm{r}$ for psykiske traumer som ikke er bevisste eller erkjente av pasienten og hennes omgivelser (Landecker, 1992).

En av de vanskeligste utfordringene for leger og annet helsepersonell (og naturligvis for familie og andre pårørende) er at svært mange borderlinepasienter med jevne mellomrom kan true med å ta sitt eget liv. Det aktualiseres gjerne i situasjoner der det er oppstått konflikt mellom pasienten og viktige andre personer. Til tross for at selvmordstruslene kan virke lite alvorlig ment, kan vi ikke uten videre avfeie dem. Studier viser at mellom 50 og 75 prosent av unders $\varnothing$ kte borderlinepasienter minst en gang i livet faktisk har gjort selvmordsfors $\varnothing \mathrm{k}$ (Mehlum et al, 1994, Linehan, 1993). Mange av disse fors $\varnothing$ kene vil det være korrekt å betegne som parasuicid, det vil si selvdestruktive handlinger som ikke først og fremst er ment å føre til død, men til en endring i den situasjonen som pasienten opplever som håpløs eller uakseptabel.

Forløpsstudier tyder på at de borderlinepasientene som har tendens til å reagere med suicidal atferd i problematiske situasjoner, har vanskeligere for å nyttiggjøre seg behandling og vil skåre betydelig svakere på viktige funksjonsmål dersom vi sammenlikner med borderlinepasienter som ikke har tendens til å reagere suicidalt (Mehlum et al, 1994). De vil også i st $\varnothing$ rre grad beholde sin borderlinediagnose selv etter lang tid. For pårørende og hjelpere kan de selvdestruktive handlingene oppleves som sterkt manipulerende, og det kan være fristende å avvise å gi hjelp. Det er imidlertid ofte slik at alvorsgraden av den suicidale atferden $\varnothing$ ker etter hvert, og oppfølgingsstudier har vist oss at pasienter som gjør sterkt manipulativt pregete selvmordsfors $\varnothing \mathrm{k}$ eller parasucid, har like høy selvmordsrate som andre borderlinepasienter.

\section{Årsaksforhold}

Hva vet vi om årsakene til den $\varnothing \mathrm{kte}$ selvmordsfaren ved personlighetsforstyrrelser? Mest nærliggende er det jo å betrakte dette som en opplagt konsekvens av alle de krenkelser og tap, konflikter og kriser som følger av den uheldige måten å forstå og forholde seg til seg selv og andre på, og den sviktende evnen til å takle sterke emosjoner som ligger særlig i borderlinesyndromet, men også i antisosial personlighetsforstyrrelse. Den ene krisen og negative livshendelsen avløser ofte den andre. Familie og venner går trett, og den sosiale st $\varnothing t t e n$ i nettverket går tapt. Alt dette gir utvilsomt en $\varnothing \mathrm{kt}$ fare for selvmordshandlinger. Slike handlinger kan være utført i sterk affekt, men også som følge av en gradvis $\varnothing$ kende opplevelse av selvforakt og håpløshet. Vi må innse at mange av dem som har alvorlige personlighetsforstyrrelser i lange perioder, har gode grunner til å $\varnothing$ nske at de var $\mathrm{d} \varnothing \mathrm{de}$.

I løpet av de siste 20-30 år har vi fătt $\varnothing$ kte kunnskaper om det biologiske grunnlaget for en del av de psykiske forstyrrelsene som medfører $\varnothing \mathrm{kt}$ selvmordsfare ved enkelte personlighetsforstyrrelser.

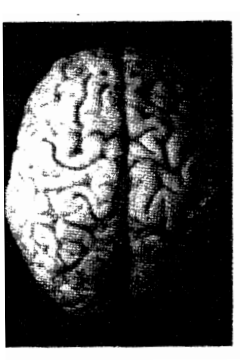
Svenske studier (Åsberg et al, 1976, Aggren, 1980) markerte et gjennombrudd i forskningen da de påviste at deprimerte pasienter som på en voldelig måte enten hadde fors $\varnothing \mathrm{kt}$ eller gjennomført selvmord, hadde lavere konsentrasjoner av serotoninmetabolitten 5-hydroksy-indol-eddiksyre (5-HIAA) i cerebrospinalvæsken. Etter hvert har det vist seg at personer med antisosial og borderline personlighetsforstyrrelse ofte har en slik forstyrret serotoninomsetning i hjernen. Dette ser ut til å medføre en svikt i affekt-og impulskontrollen som er knyttet til aggressiv, voldelig og suicidal atferd. Disse biokjemiske funnene rimer bra med kliniske unders $\varnothing$ kelser som viser oss at det er størst selvmordsrisiko blant de personlighetsforstyrrete pasientene som har svakest impulskontroll, mest uttalt antisosial atferd og mest fremtredende rusmisbruk (Kullgren, 1988). 


\section{Terapeutiske utfordringer}

Pasienter med borderline personlighetsforstyrrelse er ikke av de letteste å hjelpe. Deres uttalte tendens til å handle impulsivt, svart/hvitt tenkning og sterke følelsesmessige svingninger kan gjøre den terapeutiske relasjonen svært krevende. Pasientens bilde av terapeuten skifter ofte meget mellom idealisering og devaluering, og blant annet i takt med dette kan pasientens tro på og motivasjon for videre behandling variere sterkt.

For behandlere i m $\varnothing$ te med borderlinepasienter i suicidal krise er det særlig to utfordringer som skal takles. For det første er det jo helt avgjørende å hindre at pasienten tar sitt eget liv eller tilfører seg alvorlige og irreversible skader. Den andre utfordringen er å hjelpe pasienten til å redusere sin kroniske tendens til suicidal atferd. Hensynet til disse to utfordringene kan ofte være i konflikt. En altfor aktiv og intervenerende holdning fra terapeutens side kan på en uheldig måte bidra til å bekrefte og forsterke den negative mestringsstrategien som suicidal atferd er. I denne vanskelige balansegang kan det være klokt å følge disse prinsippene når vi i konkrete situasjoner skal vurdere og revurdere suicidalfaren:

- Aktuell og konkret suicidal atferd fokuseres alltid og ignoreres ikke.

- Men skill mellom de kroniske suicidaltankene på den ene siden og aktuelle selvmordsplaner og konkret atferd på den andre (har det oppstått endringer i suicidaltankenes intensitet eller art?).

- Gjennomgå hva som i pasientens liv har utløst de akutte følelsesmessige problemene.

- Når suicidalitet bringes på bane - gjør alltid en vurdering av den aktuelle risiko, herunder hvor lett pasienten har tilgang på selvmordsmidler.

- Vurder behov for innleggelse eller annen endring av behandlingsopplegget.

- Bekreft pasientens opplevelse av smerte.

- Søk å reinstallere håp, ta utgangspunkt i noe som realistisk sett kan endres til det positive (selv små endringer kan gi opphav til nytt håp).

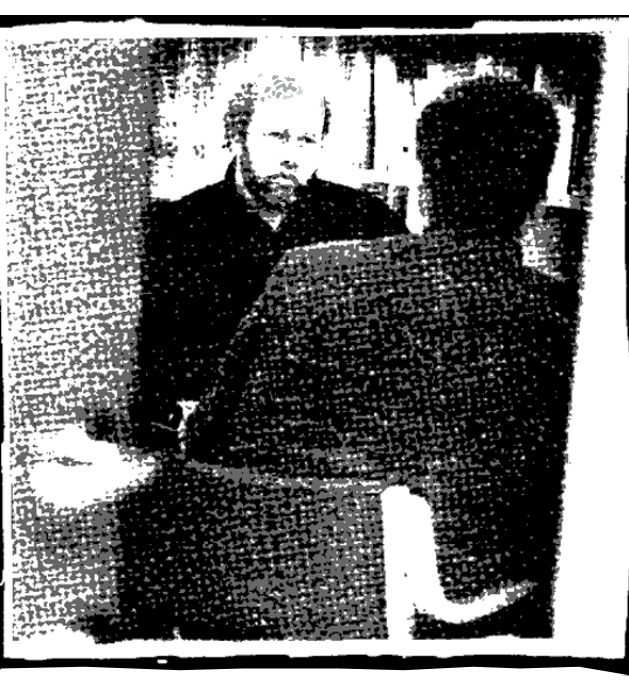

- Diskuter alternativer til suicidal atferd, og bekreft ikke-suicidal atferd.

På litt lengre sikt vil de terapeutiske utfordringene ofte bestå i å hjelpe pasienten til å bli en bedre problemløser, samtidig som pasienten under ivaretakende forhold får hjelp til å bearbeide sine intense emosjoner i kjølvannet av aktuelle krenkelser eller skuffelser. Etter hvert kan dette for mange pasienter gi opphav til mer konstruktive mestringsm $\varnothing$ nstre og bedre livskvalitet, noe som selvsagt vil svekke tendensen til suicidalitet.

Mange borderlinepasienter sliter også med depressive plager eller rusmisbruk. Som vi har sett er dette med på å $\varnothing \mathrm{ke}$ selvmordsfaren betydelig. Derfor er det viktig at slike problemer blir gjort til gjenstand for behandlingsmessige tiltak. I tillegg til at psykoterapeutiske tilnærminger kan være nyttige, vil det som regel være påkrevet med antidepressiv medikamentell behandling dersom det foreligger alvorlig depresjon. I lys av den alvorlige selvmordsfaren som ofte foreligger, b $\varnothing \mathrm{r}$ behandlende lege velge et lite toksisk preparat, for eksempel en av de selektive serotonin reopptakshemmerne.

Som vi alt har påpekt, kan det være meget krevende å arbeide med suicidale pasienter med personlighetspatologi. Ofte blir vi gjort til gjenstand for pasientens projeksjoner og overføringer. Men også vi kan komme til å reagere irrasjonelt gjennom utagering av vår egen overføring. Det kan gi opphav til en rekke kompliserende forhold i behandlingen. Samtidig kan det gi oss viktige lærdommer om oss selv, våre egne sårbare punkter og våre egne mestringsstrategier.

\section{Litteratur}

Henriksson MM. Mental disorders and comorbidity in suicide. American Journal of Psychiatry 1993; 150: 935-40.

Kjelsberg E, Eikeseth PH, Dahl AA. Suicide in borderline patients - predictive factors.

Acta Psychiatrica Scandinavica 1991; 84: 283-7.

Kullgren G. Factors associated with completed suicide in borderline personality disorder. Journal of Nervous and Mental Disease, 1988; 176: 40-4.

Landecker, $\mathrm{H}$. The role of childhood sexual trauma in the etiology of borderline personality disorder: considerations for diagnosis and treatment. Psychotherapy 1992; 29: 234-42.

Linehan MM. Cognitive behavioral treatment of borderline personality disorder. New York: Guilford, 1993

Mehlum L, Friis S, Vaglum P, Karterud S. The longitudinal pattern of suicidal behaviour in borderline personality disorder: A prospective follow-up study.

Acta Psychiatrica Scandinavica 1994; 90: 124-30.

Rich CL, Runeson BS. Similarities in diagnostic comorbidity between suicide among young people in Sweden and the United States.

Acta Psychiatrica Scandinavica 1992; 86: 335-9.

Stone MH. The fate of borderline patients.

Successful outcome and psychiatric practice. New York: Guilford, 1987.

Agren H. Symptom patterns in unipolar and bipolar depression correlating with monoamine metabolites in the cerebrospinal fluid: II. Suicide. Psychiatry Research 1980; 3: 225-36.

Åsberg M, Träskman L, Thorén P.

5-HIAA in the cerebrospinal fluid:

A biochemical suicide predictor.

Archives of General Psychiatry 1976; 33: 1193-7.

\section{Suicidologi på Internett}

Seksjon for selvmordsforskning og -forebygging legger alle artikler i samtlige nummer av Suicidologi ut på nettet. Adressen er:

http://www.med.uio.no/ipsy/ssff/ 